\title{
PERSEPSI ANAK TERHADAP KEHARMONISAN ORANG TUA DAN KEMANDIRIAN ANAK
}

\author{
Lisa Ratriana Chairiyati \\ Jurusan Psikologi, Fakultas Psikologi, Bina Nusantara University \\ Jln. Kemanggisan Ilir III No 45, Kemanggisan, Palmerah, Jakarta Barat 11480
}

\begin{abstract}
This reseach was conducted to learn the connection between children's perception toward parents harmonic relationship and children independence on junior high school in Bekasi. The research planning is correlation with samples of 100 active students in extracurricular program. The data is gathered in cluster random sampling technique using questionnaire. This research uses 2 instruments, that are parents harmony scale and children's independence scale. Next, data analysis is done to 100 research respondents using correlation statistic calculation of Product Moment Pearson in significancy rate 0,05 which entered into computer program of SPSS 15.0 for Windows. From data analysis came statistic descriptive which shows that children's perception is between 6,00-8,00 score, means that according to the children, parents' relationships are quite harmony to harmonious. Meanwhile, children's perception about parents' harmonious relationship has 5,80-8,00 score; which concluded that there is connection between children's perception about parents' harmonious relationship with children's independency at school, where the more harmony the parents are the more independent the children are.
\end{abstract}

Keywords: perception, self concept, parents harmonious, children's independency, Product Moment Pearson correlation

\begin{abstract}
ABSTRAK
Penelitian ini bermaksud untuk mempelajari bagaimana hubungan antara persepsi anak terhadap keharmonisan orang tua dan kemandirian anak pada siswa Sekolah Menengah Pertama di Kota Bekasi. Rancangan penelitiannya adalah korelasional dengan sampel berjumlah 100 siswa-siswi yang aktif di program ekstrakurikuler. Data dikumpulkan dengan teknik cluster random sampling dengan menggunakan kuesioner. Penelitian ini menggunakan 2 buah instrument yaitu skala keharmonisan orang tua dan skala kemandirian anak. Selanjutnya analisis data dilakukan terhadap 100 responden penelitian dengan menggunakan perhitungan statistik korelasi Product Moment Pearson dengan taraf signifikansi 0,05 yang dimasukkan dalam program computer SPSS 15.0 for Windows. Hasil analisis data diperoleh secara statistic deskriptif menunjukkan bahwa persepsi anak tentang keharmonisan orang tua mempunyai nilai 6,00-8,00, berarti keharmonisan orang tua menurut pandangan anak cukup harmonis sampai harmonis. Sedangkan, persepsi anak tentang keharmonisan orang tua mempunyai nilai 5,80-8,00; sehingga disimpulkan bahwa terdapat hubungan antara persepsi anak tentang keharmonisan orang tua dengan kemandirian anak di mana semakin harmonis orang tua maka anak semakin mandiri.
\end{abstract}

Kata kunci: persepsi, konsep diri, keharmonisan orang tua, kemandirian anak, korelasi Product Moment Pearson 


\section{PENDAHULUAN}

Anak mandiri biasanya mampu mengatasi persoalan yang menghadangnya. Kemandirian sangat erat terkait dengan anak sebagai individu yang mempunyai konsep diri, penghargaan terhadap diri sendiri (self esteem), dan mengatur diri sendiri (self regulation). Anak paham akan tuntutan lingkungan terhadap dirinya, dan menyesuaikan tingkah lakunya (Sari, 2001). Secara umum kemandirian bisa dilihat dari tingkah laku. Namun, kemandirian tidak selalu berbentuk fisik yang ditampilkan dalam tingkah laku. Ada bentuk emosional dan sosialnya. Anak yang mandiri mampu untuk memenuhi tuntutan lingkungannya. Contohnya, anak usia 3-4 tahun yang sudah bisa menggunakan alat makan, harusnya bisa makan sendiri (Verauli, 2004). Hal demikian ini yang dimaksud kemandirian. Menurut beberapa psikolog kemandirian terbentuk dari lingkungan keluarga yang baik, dalam arti keluarga yang harmonis dan kemandirian itu tentu harus dilatih sejak dini. Menurut psikolog yang kerap disapa Vera ini, anak mampu berpisah dalam waktu singkat dengan orangtuanya, misalnya saat mulai bersekolah. Anak bisa masuk ke kelas dengan nyaman karena mampu mengontrol dirinya. Ini bentuk secara emosional.

Pengertian mandiri adalah suatu suasana dimana seseorang mau dan mampu mewujudkan kehendak dirinya yang terlihat dalam tindakan nyata guna menghasilkan sesuatu (barang atau jasa) demi pemenuhan kebutuhan hidupnya dan sesamanya (Atosokhi, 2002). Dari pengertian tersebut terlihat bahwa mandiri selalu berhubungan dengan manusia yang sedang melaksanakan kegiatan tersendiri atau bekerja sehingga muncul ungkapan bahwa bekerja mandiri/wiraswasta yang merupakan lawan dari bekerja pada orang lain. Kemandirian merupakan suatu sikap individu yang diperoleh secara kumulatif selama dalam perkembangan, dimana individu akan terus menerus belajar untuk bersikap mandiri dalam menghadapi berbagai situasi di lingkungannya, sehingga individu pada akhirnya akan mampu berpikir dan bertindak sendiri. Untuk dapat hidup mandiri seseorang membutuhkan kesempatan, dukungan dan dorongan dari keluarga serta lingkungan di sekitarnya. Pada saat ini peran orang tua sangat diperlukan bagi anak sebagai penguat untuk setiap perilaku yang telah dilakukannya.

Sebagian besar anak hidup di lingkungan keluarga. Pendidikan di keluarga akan memberi landasan bagi kehidupan dimasa mendatang. Oleh karena itu perilaku anak sangat dominan dipengaruhi oleh lingkungan khususnya lingkungan keluarganya (Anwas, 1998). Beberapa pakar psikologi mengatakan bahwa apa yang dialami anak di masa kecil, akan membekas dalam diri anak dan mewarnai kehidupannya kelak. Barangkali munculnya berbagai masalah remaja, seperti perkelahian, tawuran narkotika, dan premanisme lainnya bisa saja disebabkan kurang harmonisnya lingkungan keluarga saat ini yang cenderung mengkhawatirkan. Keluarga yang harmonis biasanya merupakan keluarga yang memegang teguh nilai, etika, dan moral serta orang tua benar-benar menjadi panutan bagi anaknya sehingga pada akhirnya menjadi anak-anak yang baik. Artinya menciptakan keluarga yang harmonis sangat penting sebagai benteng bagi dari perilaku negatif di kalangan anak dan remaja.

Mungkin akan lebih yakin terhadap temuan Coles apabila mengkaji bagaimana proses pembentukan perilaku manusia. Pembentukan perilaku didasarkan pada stimulus yang diterima melalui panca indra yang kemudian diberi arti dan makna berdasarkan pengetahuan, pengalaman, dan keyakinan yang dimilikinya. Anak, sebagai individu yang masih labil dan sedang mencari jati diri, sangat rentan dengan perilaku peniruan yang akhirnya akan terinternalisasi dan membentuk pada kepribadiannya. Komunikasi dan teladan/contoh orang tua dalam perilaku sehari-hari akan membuat benteng yang kokoh dalam rangka membendung semua pengaruh buruk dari luar yang pada akhirnya akan menumbuhkan kemandirian anak. 
Dengan demikian diharapkan hubungan keluarga yang sehat dan bahagia menimbulkan dorongan untuk anak berprestasi sehingga akan membuat rasa percaya diri yang kuat pada anak, yang apada akhirnya anak menjadi mandiri. Sebaliknya hubungan yang tidak sehat dan tidak bahagia/harmonis akan menimbulkan ketegangan emosional yang biasanya akan memberi efek yang buruk pada kemampuan berkonsentrasi dan kemampuan untuk belajar yang pada akhirnya rasa percaya diri menjadi berkurang dan akan berakibat kurang baik bagi anak.

Keluarga merupakan produsen dan konsumen sekaligus, dan harus mempersiapkan dan menyediakan segala kebutuhan sehari-hari kehidupan rumah tangganya. Setiap anggota keluarga dibutuhkan dan saling membutuhkan satu sama lain, supaya mereka dapat hidup lebih senang dan tenang. Masing-masing anggota keluarga mempunyai peranan yang penting dalam roda kehidupan serta dibutuhkan oleh anggota linnya.

Tokoh ayah dan ibu dalam keluarga mempunyai peranan yang sangat besar dalam menciptakan kesejahteraan umum melalui bimbingan dan pendidikan anaknya secara bertanggung jawab (Yulia, 1993). Pada umumnya peran ayah dan ibu sudah diatur sedemikian rupa, sehingga ibu lebih banyak berhubungan dengan anak dan mempunyai kesibukan rumah tangganya di dalam rumah. Sebaliknya ayah lebih banyak melakukan kegiatan diluar rumah. Lingkungan diluar rumah justru lebih banyak mengalami perubahan-perubahan. Ayah atau suami mau tak mau harus mengikuti dan menyesuaikan diri pada setiap perubahan dalam pekerjaannya dan tempatnya di lingkungan masyarakatnya. Suami mengalami suatun proses hidup psikis yang lebih dinamis dibanding isterinya, sehingga akan membentuk perbedaan kehidupan psikis mereka mengalami jarak yang makin membesar sehingga membentuk jurang yang tidak memungkinkan kontak lagi.

Hal-hal yang seperti ini perlu dihindari dengan cara perlu adanya keakraban dalam hubungan persahabatan antara suami dan isteri yang ditandai dengan usaha suami menarik isteri sedemikian rupa dan mengajaknya bersama-sama mengikuti setiap perubahan dan perkembangannya. Sehingga kehilangan kontak psikis yang dikawatirkan terjadi, tidak akan terjadi. Sebaliknya isteri harus mengikut sertakan suami dalam setiap perubahan yang terjadi melalui penyelesaian masalah demi masalah yang di hadapinya. Khususnya perubahan dan perkembangan suasana rumah yang turut serta dibentuk oleh anggota keluarga lainnya. Pengetahuan penting mengenai setiap perkembangan menyebabkan tokoh ayah tetap merupakan salah seorang anggota dari suatu sistem keluarga, dan tidak menjadi orang asing dirumahnya sendiri.

Dalam sebuah sistem keluarga terlihat bahwa adanya kepentingan peranan tokoh ayah dan ibu dalam membina suasana keluarga yang diperlukan bagi perkembangan pribadi anak agar menjadi pribadi yang dewasa dan harmonis. Di dalam sebuah keluarga, sepasang suami isteri haruslah memperhatikan kesatuan yang harmonis. Kesatuan ayah dan ibu adalah sedemikian pentingnya sebagai alas yang kuat dalam berkeluarga, sehingga bilamana kesatuan ini kurang kuat, maka akan dapat menyebabkan kegoncangan dalam keluarga dengan segala akibatnya, baik secara khusus dalam keluarga itu sendiri maupun dalam kehidupan masyarakatnya.

Untuk menghindari kesatuan yang kurang kuat ini maka pertama-tama di dalam rumah haruslah diciptakan sedemikian rupa sehingga menjamin timbulnya suasana dan perasaan aman. Dengan demikian sangatlah wajar jika kepribadian seseorang pertama terbentuk sebagai hasil dari perpaduan antara warisan sifat-sifat, bakat-bakat orang tua dan lingkungan lingkungan keluarganya sendiri dimana sang anak berkembang. Dari semua anggota keluarga, yakni ayah, ibu dan saudarasaudaranya, sang anak akan memperoleh segala kemampuan dasar baik secara intelektual maupun sosial. Bahkan untuk penyaluran emosi banyak ditiru dari anggota-anggota lain dalam keluarganya. Sikap, pandangan dan pendapat orang tua atau anggota keluarga yang lainnya akan dijadikan model oleh si anak dan ini kemudian menjadikan sebagian dari tingkah laku anak itu sendiri dalam kehidupan sehari-hari. 
Keharmonisan orang tua merupakan hal yang penting dalam menjaga keutuhan sebuah keluarga. Kehidupan sebuah keluarga yang selaras atau harmonis merupakan dambaan hampir setiap orang. Kehidupan yang harmonis hanya dapat dicapai apabila setiap individu yang bersangkutan dapat menciptakannya sendiri tentunya. Orang lain atau lingkungan sekitarnya sifatnya hanya bersifat sekedar mengiringi kehidupan orang tersebut. Orang yang kehidupannya harmonis berarti sebenarnya dia telah mampu menyesuaikan diri dengan lingkungannya secara normatif, selaras dan seimbang. Hal itu bisa diartikan bahwa individu tersebut tidak menunjukkan perilaku-perilaku yang berlebihan sehingga dapat menimbulkan benturan terhadap sesamanya. Disamping itu ia juga tidak menunjukkan perilaku yang kurang baik sehingga tidak merepotkan orang lain. Keharmonisan kehidupan keluarga seseorang bersumber dari proses perkembangan dan pendidikan yang diperoleh dan dialami oleh setiap orang.

Peranan yang aktif dari kedua orang tua dalam proses perkembangan terhadap anak-anaknya merupakan hal yang sangat penting. Seperti telah disebutkan di bagian depan bahwa perkembangan konsep diri anak sangat bergantung dari kematangan, pengalaman serta pengetahuan anak. Hal ini yang menyebabkan bahwa peranan orang tua untuk mengarahkan pematangan konsep diri anak secara terencana dan terarah dengan tujuan agar dapat membangun rasa percaya diri pada anak.

Sedangkan kemandirian anak dalam perkembangannya berkaitan dengan keharmonisan orang tua. Kemandirian anak dalam perkembangannya sangat bergantung pada lingkungan, terutama pada lingkungan terdekat, yaitu lingkungan keluarga. Dimana perilaku dan kehidupan orang tua sehari-hari akan selalu melekat pada pikiran anak. Dengan demikian diharapkan hubungan keluarga yang sehat dan bahagia akan menimbulkan dorongan untuk anak berprestasi yang baik sehingga akan membuat rasa percaya diri yang kuat pada anak. Sebaliknya hubungan yang tidak sehat dari kedua orang tua dalam arti kurang/tidak harmonis akan menimbulkan ketegangan emosional yang biasanya akan memberi efek yang buruk bagi anak.

Berdasarkan fenomena-fenomena diatas menarik perhatian bagi peneliti untuk mengetahui lebih jauh tentang berbagai masalah yang melibatkan bagaimana peranan orang tua terhadap tingkah laku anak, pandangan umum anak tentang kehidupan orang tuanya, disamping juga bagaimana tingkah laku kehidupan anak sehari-hari. Dalam penelitian ini hipotesis penelitian adalah terdapat hubungan antara persepsi anak terhadap keharmonisan orang tua dengan kemandirian anak.

\section{METODOLOGI PENELITIAN}

Desain dalam penelitian ini yang digunakan adalah dengan menggunakan rancangan korelasional, dalam hal ini adalah hubungan antara persepsi anak terhadap keharmonisan orang tua dan kemandirian anak pada siswa/siswi Sekolah Menengah Pertama di Bekasi sebagai obyek penelitian. Subyek dalam penelitian ini adalah anak-anak sekolah (siswa/siswi SMP Swasta yang berkedudukan di Bekasi), yang terdaftar aktif di program ekstra kurikuler dan berusia antara 12-14 tahun. Pemilihan subyek penelitian adalah anak-anak sekolah dalam kategori remaja ini dimaksudkan karena asumsi peneliti bahwa pada usia tingkat remaja mulai banyak membuat permasalahan dengan lingkungan maupun dengan orang tuanya. Dalam penelitian ini pengambilan sampel dilakukan adalah dengan menggunakan teknik cluster random sampling.

Data penelitian yang diperoleh dari data bagian tata usaha sebuah SMP swasta yang berkedudukan di Bekasi dengan jumlah populasi yang memenuhi ciri-ciri subyek penelitian yaitu siswa/siswi yang terdaftar aktif di program ekstra kurikuler dan berusia antara 12 - 14 tahun berjumlah sekitar 100 orang. Penelitian ini dilakukan di sebuah Sekolah Menengah Pertama swasta yang berkedudukan di Bekasi yang terletak sekitar $30 \mathrm{~km}$ dari Jakarta. Lokasi penelitian tersebut adalah Sekolah Menengah Pertama di Jl. Jawa, Perumnas III Bekasi 17111. 
Instrumen yang digunakan dalam penelitian ini adalah skala tingkat keharmonisan orang tua dan skala kemandirian anak di Sekolah Menengah Pertama di Bekasi, yang dibuat sendiri oleh penulis dalam bentuk kuesioner. Kuesioner ini dibuat berdasarkan teori-teori dan aspek-aspek yang mengacu pada uraian-uraian yang telah dipaparkan diatas, selanjutnya dibuat pernyataan-pernyataan untuk dipilih sesuai dengan pendapat responden.

Penelitian ini menggunakan 2 (dua) buah instrumen, yaitu skala keharmonisan orang tua dan skala kemandirian anak. Kedua instrument ini digunakan untuk mengungkap bagimana hubungan persepsi antara keharmonisan orang tua dan kemandirian anak. Skala keharmonisan orang tua dan skala kemandirian anak dibuat berdasarkan pada Skala Thurstone, dimana dilakukan dengan meminta responden untuk memilih pernyataan yang ia setujui dari beberapa pernyataan-pernyataan yang menyajikan pandangan berbeda-beda. Untuk pernyataan yang tidak ia setujui tidak perlu dipilih atau dicantumkan sehingga diharapkan responden bebar-benar hanya memilih pernyataan yang sesuai dengan kata hatinya.

Pemberian nilai Skala Thurstone ini dilakukan setelah responden memilih pernyataan yang mempunyai asosiasi nilai antara 1 sampai dengan 10, tetapi nilai tersebut tidak diketahui oleh responden. Pemberian nilai skala ini berdasarkan jumlah tertentu pernyataan yang dipilih oleh responden mengenai angket tersebut. Untuk nilai skala kemandirian anak berdasarkan pernyataan yang menyajikan pandangan yang berbeda-beda.

Pernyataan tentang kemandirian anak ada 10 jenis pernyataan, pernyataan tersebut adalah: (1) saya diakui sebagai siswa yang layak dihormati dan dihargai; (2) saya menetapkan tujuan hidup diri saya sendiri; (3) saya mengkritik tindakan saya dan bukan diri saya; (4) saya belajar secara teratur setiap malam hari kecuali hari libur; (5) lingkungan (teman-teman) saya belajar mendorong untuk belajar hal-hal yang baru; (6) saya senang mencari teman yang berpikir positif; (7) saya mampu menyelesaikan pekerjaan rumah termasuk menyelesaikan tugas sekolah dengan baik; (8) saya selalu belajar untuk diterima/ diakui dengan baik oleh teman-teman saya; (9) saya membantu orangtua menyelesaikan pekerjaan dirumah yang menjadi tanggung jawab saya; (10) saya bisa membagi waktu untuk kegiatan-kegiatan yang saya lakukan. Berdasarkan 10 pernyataan tentang kemandirian anak tersebut, dapat dianalisis sehingga didapatkan nilai skala pernyataan tentang kemandirian anak.

Sedangkan untuk penentuan skala keharmonisan orang tua berdasakan pada kuesioner pernyataan tentang keharmonisan orang tua ada 10 jenis pernyataan yang berbeda, pernyataan tersebut adalah: (1) ayah dan ibu saya selalu ingat akan hari ulang tahun seluruh anggota keluarga yang ada; (2) kebiasaan keluarga saya adalah selalu makan bersama, paling tidak satu kali dalam sehari; (3) ibu saya selalu membuatkan minuman baik pagi maupun sore untuk ayah; (4) di dalam keluarga saya ada aturan rumah tangga yang selalu harus ditaati oleh semua anggota keluarga; (5) ada pembagian tugas sehari-hari bagi seluruh anggota keluarga saya; (6) ayah dan ibu saya selalu melakukan sholat berjamaah; (7) ayah dan ibu saya tidak pernah bertengkar; (8) ayah dan ibu saya tidak membedabedakan perhatian pada anak-anaknya; (9) ayah dan ibu saya selalu memberikan apa yang dibutuhkan oleh anak-anaknya; (10) ayah dan ibu sering mengajak semua anggota keluarga untuk berekreasi pada waktu liburan. Dengan cara yang sama berdasarkan 10 pernyataan tentang keharmonisan orang tua tersebut di atas, dapat dianalisis sehingga didapatkan nilai skala pernyataan tentang keharmonisan orang tua.

Tahapan yang sangat penting dalam proses penelitian adalah menyusun alat ukur (instrument) penelitian sebagai pedoman untuk mengukur variable-variabel penelitian. Alat ukur tersebut haruslah valid dan reliable, melalui analisis validitas dan reliabilitas atau bisa juga menggunakan alat ukur baku yang digunakan untuk mengukur berbagai variable-variabel social dan psikologi. Uji validitas ini adalah dengan melakukan berbagai analisis skor butir dengan skor total untuk melihat kesahihan berdasarkan koefisien korelasi antara keduanya. Kesahihan ditentukan berdasarkan pada tingkat keyakinan koefisien korelasi pada taraf keberartian / signifikan sebesar 5\%. Untuk menguji kesahihan 
masing-masing factor tersebut, butir-butir yang valid selanjutnya dikumpulkan untuk dilakukan analisis korelasi antara faktor dengan cara mengkorelasikan skor total tiap faktor dengan total skor seluruh faktor.

Untuk reliabilitas instrumen yang diteliti adalah internal dari konsistensi yang diukur dengan menggunakan teknik korelasi, dimana variable-variabelnya diukur dua kali pada waktu yang sama atau bisa dikatakan hampir bersamaan. Sedangkan untuk mencari reliabilitas maka dicari korelasi antara kedua hasil ukuran tersebut dengan cara mencari koefisien korelasi Spearman. Selanjutnya mencari koefisen reliabilitas yang dipakai sebagai alat ukur yang terpercaya. Selanjutnya secara teknik, analisis ini dilakukan dengan menggunakan teknologi komputer program SPSS (Statistical Package for Social Science) versi 15 for windows dengan rumus korelasi product moment Pearson.

Prosedur penelitian dalam hal ini dimulai dari tahap persiapan dilanjutkan dengan tahap pelaksanaan penelitian ini diawali dengan pengambilan data penelitian dengan menggunakan alat ukur berupa kuesioner yang diberikan langsung kepada responden, dilanjutkan dengan pengolahan data dan analisis data dengan menggunakan program teknologi komputer program SPSS (Statistical Package for Social Science) versi 15 for windows dengan rumus korelasi product moment Pearson.

\section{HASIL DAN PEMBAHASAN}

Gambaran data penelitian terhadap 100 responden tentang hubungan antara persepsi anak terhadap keharmonisan orang tua dengan kemandirian anak, dengan menggunakan 2 buah instrument (skala keharmonisan orang tua dan skala kemandirian anak) diperlihatkan pada tabel data hasil penilaian responden (Tabel 1).

Tabel 1 Data Hasil Penilaian Responden

\begin{tabular}{|c|c|c|c|c|c|}
\hline Subyek & $\begin{array}{c}\text { Keharmonisan } \\
\text { orang tua }\end{array}$ & $\begin{array}{c}\text { Kemandirian } \\
\text { anak }\end{array}$ & Subyek & $\begin{array}{l}\text { Keharmonisan } \\
\text { orang tua }\end{array}$ & $\begin{array}{c}\text { Kemandirian } \\
\text { anak }\end{array}$ \\
\hline 1 & 7,6 & 7,4 & 51 & 7,2 & 7,6 \\
\hline 2 & 7,6 & 7,8 & 52 & 7,4 & 6,8 \\
\hline 3 & 7,8 & 7,6 & 53 & 7,6 & 6,8 \\
\hline 4 & 7,2 & 7,8 & 54 & 7,8 & 7,8 \\
\hline 5 & 7,8 & 7,6 & 55 & 6,0 & 5,8 \\
\hline 6 & 7,8 & 7,6 & 56 & 7,2 & 7,4 \\
\hline 7 & 7,6 & 7,8 & 57 & 7,4 & 6,8 \\
\hline 8 & 7,8 & 7,8 & 58 & 6,6 & 6,8 \\
\hline 9 & 7,8 & 8,0 & 59 & 6,4 & 6,6 \\
\hline 10 & 7,8 & 7,8 & 60 & 6,8 & 6,4 \\
\hline 11 & 7,4 & 7,4 & 61 & 6,8 & 6,2 \\
\hline 12 & 7,8 & 7,4 & 62 & 8,0 & 7,8 \\
\hline 13 & 7,4 & 7,2 & 63 & 7,8 & 7,0 \\
\hline 14 & 8,0 & 7,8 & 64 & 7,6 & 7,4 \\
\hline 15 & 7,0 & 6,8 & 65 & 7,4 & 7,6 \\
\hline 16 & 8,0 & 7,8 & 66 & 7,2 & 7,8 \\
\hline 17 & 7,6 & 7,2 & 67 & 7,2 & 7,8 \\
\hline 18 & 7,6 & 7,4 & 68 & 7,8 & 7,6 \\
\hline 19 & 7,8 & 6,8 & 69 & 6,8 & 7,4 \\
\hline 20 & 7,8 & 8,0 & 70 & 6,8 & 6,8 \\
\hline 21 & 6,8 & 6,6 & 71 & 6,8 & 7,2 \\
\hline 22 & 7,8 & 8,0 & 72 & 7,0 & 7,2 \\
\hline 23 & 7,6 & 7,4 & 73 & 7,0 & 7,4 \\
\hline 24 & 7,6 & 7,4 & 74 & 7,6 & 7,4 \\
\hline 25 & 7,8 & 7,4 & 75 & 7,6 & 7,0 \\
\hline 26 & 7,0 & 6,8 & 76 & 7,2 & 7,8 \\
\hline 27 & 7,8 & 7,6 & 77 & 7,0 & 6,8 \\
\hline 28 & 7,8 & 7,6 & 78 & 7,0 & 6,8 \\
\hline 29 & 7,6 & 7,4 & 79 & 7,0 & 6,8 \\
\hline
\end{tabular}


Tabel 1 Data Hasil Penilaian Responden (lanjutan)

\begin{tabular}{cccccc}
\hline Subyek & $\begin{array}{c}\text { Keharmonisan } \\
\text { orang tua }\end{array}$ & $\begin{array}{c}\text { Kemandirian } \\
\text { anak }\end{array}$ & Subyek & $\begin{array}{c}\text { Keharmonisan } \\
\text { orang tua }\end{array}$ & $\begin{array}{c}\text { Kemandirian } \\
\text { anak }\end{array}$ \\
\hline 30 & 8,0 & 7,8 & 80 & 7,0 & 8,0 \\
31 & 7,4 & 7,2 & 81 & 7,8 & 8,0 \\
32 & 7,2 & 7,0 & 82 & 6,0 & 8,0 \\
33 & 7,4 & 7,2 & 83 & 6,4 & 6,6 \\
34 & 7,8 & 7,0 & 84 & 6,4 & 7,0 \\
35 & 7,4 & 7,8 & 85 & 6,8 & 6,4 \\
36 & 7,8 & 7,6 & 86 & 6,8 & 6,6 \\
37 & 7,8 & 7,6 & 87 & 6,8 & 6,6 \\
38 & 7,8 & 8,0 & 88 & 7,8 & 7,6 \\
39 & 7,8 & 7,6 & 89 & 7,2 & 8,0 \\
40 & 7,8 & 7,6 & 90 & 7,8 & 7,6 \\
41 & 7,8 & 7,6 & 91 & 7,8 & 6,4 \\
42 & 7,8 & 7,6 & 92 & 6,2 & 6,0 \\
43 & 7,8 & 7,6 & 93 & 6,4 & 7,4 \\
44 & 8,0 & 7,8 & 94 & 7,2 & 6,0 \\
45 & 8,0 & 7,8 & 95 & 6,2 & 7,0 \\
46 & 8,0 & 7,8 & 96 & 6,8 & 8,0 \\
47 & 7,4 & 7,0 & 97 & 8,0 & 8,0 \\
48 & 7,2 & 6,8 & 98 & 8,0 & 8,0 \\
49 & 7,8 & 7,6 & 99 & 8,0 & 8,0 \\
50 & 7,8 & 7,6 & 100 & 7,8 & \\
\hline
\end{tabular}

Tabel 2 Frekuensi Nilai Skala Pernyataan tentang Keharmonisan Orang Tua

\begin{tabular}{cccccc}
\hline & & Frequency & Percent & Valid Percent & Cumulative Percent \\
\hline Valid & 6.00 & 2 & 2.0 & 2.0 & 2.0 \\
& 6.20 & 2 & 2.0 & 2.0 & 4.0 \\
& 6.40 & 4 & 4.0 & 4.0 & 8.0 \\
& 1 & 1.0 & 1.0 & 9.0 \\
6.60 & 10 & 10.0 & 10.0 & 19.0 \\
6.80 & 8 & 8.0 & 8.0 & 27.0 \\
7.00 & 10 & 10.0 & 10.0 & 37.0 \\
7.20 & 9 & 9.0 & 9.0 & 46.0 \\
7.40 & 12 & 12.0 & 12.0 & 58.0 \\
7.60 & 32 & 32.0 & 32.0 & 90.0 \\
7.80 & 10 & 10.0 & 10.0 & 100.0 \\
8.00 & 100 & 100.0 & 100.0 & \\
\hline Total & & & &
\end{tabular}

Tabel 3 Frekuensi Nilai Skala Pernyataan tentang Kemandirian Anak

\begin{tabular}{cccccc}
\hline & Frequency & Percent & Valid Percent & Cumulative Percent \\
\hline Valid & 5.80 & 1 & 1.0 & 1.0 & 1.0 \\
& 6.00 & 2 & 2.0 & 2.0 & 3.0 \\
& 6.20 & 1 & 1.0 & 1.0 & 4.0 \\
6.40 & 3 & 3.0 & 3.0 & 7.0 \\
6.60 & 5 & 5.0 & 5.0 & 12.0 \\
6.80 & 12 & 12.0 & 12.0 & 24.0 \\
7.00 & 7 & 7.0 & 7.0 & 31.0 \\
7.20 & 6 & 6.0 & 6.0 & 37.0 \\
7.40 & 14 & 14.0 & 14.0 & 51.0 \\
7.60 & 20 & 20.0 & 20.0 & 71.0 \\
7.80 & 17 & 17.0 & 17.0 & 88.0 \\
8.00 & 12 & 12.0 & 12.0 & 100.0 \\
\hline Total & 100 & 100.0 & 100.0 & \\
\hline
\end{tabular}


Tabel 4 Deskriptif Statitik Nilai Skala

\begin{tabular}{lccccc}
\hline & $\mathrm{N}$ & Minimum & Maximum & Mean & Std. Deviation \\
\hline Keharmonisan & 100 & 6.00 & 8.00 & 7.4000 & .51168 \\
$\begin{array}{l}\text { Orang Tua } \\
\text { Kemandirian Anak }\end{array}$ & 100 & 5.80 & 8.00 & 7.3420 & .52516 \\
\hline Valid N (listwise) & 100 & & & & \\
\hline
\end{tabular}

Tabel 5 Korelasi

\begin{tabular}{llrr}
\hline & & $\begin{array}{c}\text { Keharmonisan } \\
\text { Orang Tua }\end{array}$ & $\begin{array}{c}\text { Kemandirian } \\
\text { Anak }\end{array}$ \\
\hline $\begin{array}{l}\text { Keharmonisan } \\
\text { Orang Tua }\end{array}$ & Pearson Correlation & 1 & $.704\left(^{* *}\right)$ \\
& Sig. (2-tailed) & 100 & .000 \\
& $\mathrm{~N}$ & $.704(* *)$ & 100 \\
Kemandirian Anak & Pearson Correlation & .000 & 1 \\
& Sig. (2-tailed) & 100 & 100 \\
\hline
\end{tabular}

** Correlation is significant at the 0.01 level (2-tailed).

Selain itu, dengan menggunakan perhitungan statistic korelasi Product Moment Pearson taraf signifikansi 0,05 yang dimasukkan dalam program computer SPSS 15.0 for Windows yang diperlihatkan secara deskriptif statistic seperti tabel frekuensi, tabel deskriptif ( nilai minimum, nilai maksimum, rata-rata serta standar deviasi) tentang skala keharmonisan orang tua dan kemandirian anak.

Berdasarkan dari hasil analisis data yang dilakukan dengan program computer SPSS 15.0 for Windows sehingga diperoleh hasil secara statistic deskriptif. Dari Tabel 2 (Frekuensi Nilai Skala Pernyataan Tentang Keharmonisan Orang Tua) menunjukkan bahwa persepsi anak tentang keharmonisan orang tua mempunyai nilai $(6,00$ sampai 8,00$)$, hal ini menunjukkan bahwa keharmonisan orang tua menurut pandangan anak cukup harmonis sampai harmonis. Sedangkan dari Tabel 3 (Frekuensi Nilai Skala Pernyataan Tentang Kemandirian Anak) menunjukkan bahwa persepsi anak tentang keharmonisan orang tua mereka mempunyai nilai (5,80 sampai 8,00$)$, dengan rata-rata hampir sama yaitu 7,4 dan 7,342.dan standar deviasi hampir sama 0,51168 dan 0,52516 (Tabel 4).

Untuk hasil analisis data hubungan antara persepsi anak terhadap keharmonisan orang tua dengan kemandirian anak menunjukkan adanya hubungan (korelasi) yang cukup kuat, hal ini ditunjukkan oleh adanya angka 0,704 (Tabel 5). Angka 0,704 menunjukkan bahwa adanya arah korelasi adalah positif, atau semakin harmonis orang tua maka kecenderungan anak semakin mandiri. Dengan Nilai probabilita (Sig 2 tailed) $p=0.000$ dan ini tentunya lebih kecil dari taraf signifikansi yang ditentukan ( $\mathrm{p}<0.05$ ), hal ini menunjukkan bahwa kedua variable tersebut (keharmonisan orang tua dan kemandirian anak) memang secara nyata berkorelasi. Maka bisa dikatakan bahwa adanya keterkaitan antara hubungan antara persepsi anak tentang keharmonisan orang tua dengan kemandirian anak. Hal ini bisa juga dilihat dari adanya tanda $\left({ }^{* *}\right)$ pada angka korelasi, yang artinya sama, yaitu angka korelasi memang signifikan. 


\section{SIMPULAN}

Berdasarkan pada hasil analisis yang dilakukan, diperoleh angka/ koefisien korelasi sebesar 0,704.dengan nilai $\mathrm{p}$ (Sig 2 tailed) $\mathrm{p}=0.000$ dan $\mathrm{p}<0.05$, sehingga memiliki kesimpulan terdapat adanya hubungan antara persepsi anak tentang keharmonisan orang tua dengan kemandirian anak dimana semakin harmonis kehidupan orang tua maka kecenderungan anak semakin mandiri. Hal ini menjawab hipotesis penelitian yang dikemukakan diatas bahwa Terdapat hubungan antara persepsi anak terhadap keharmonisan orang tua dengan kemandirian anak. Berdasarkan hasil analisis berupa kesimpulan, peneliti mengemukakan beberapa saran yang mungkin nantinya bermanfaat, antara lain (1) di tempat penelitian khususnya dan ditempat lain pada umumnya perlu lebih meningkatkan hubungan yang baik antara pihak sekolah dengan orang tua siswa dengan jalan menjalin tali silaturahmi yang lebih erat antara pihak sekolah dengan orang tua siswa; (2) bagi Sekolah perlu untuk menjaga lingkungan sekolah yang selalu kondusif untuk proses pembelajaran yang baik, dengan cara lebih meningkatkan kualitas ekstra kurikuler agar bisa merangkul sebanyak mungkin siswa uintuk aktif; (3) perlunya untuk dilakukan penelitian lanjutan dengan berbagai modifikasi (instrument penelitian) yang bertujuan untuk lebih bisa mengendalikan siswa agar bisa diarahkan sesuai dengan tujuan sekolah tersebut.

\section{DAFTAR PUSTAKA}

Anwas, (1998). Perilaku Anak Hubungannya dengan Lingkungan Keluarga. Jakarta: PT BPK Gunung Mulia.

Atosokhi, dkk. (2002). Relasi dengan Diri Sendiri. Jakarta: PT Elex Media Komputindo, Kelompok Gramedia.

Sari. (2001). Kemandirian Anak dan Lingkungannya. Jakarta: CV Alfabeta.

Verauli, (2004). Bagaimana Menumbuhkan Kemandirian Anak. Jakarta: Empati Development Center.

Yulia. (1993).

\section{RIWAYAT PENULIS}

Lisa Ratriana Chairiyati lahir di Jakarta pada 21 Mei 1966. Penulis menamatkan pendidikan S1 di Universitas Padjadjaran, Bandung dalam bidang Ilmu Komunikasi pada 1992. Kandidat S2 di Universitas Tarumanagara dalam bidang Psikologi Pendidikan ini bekerja sebagai Dosen full time Fakultas Psikologi di Binus University. 